\title{
Identifikasi Hidden Competence dan Pengaruhnya Terhadap Kinerja Guru Daerah Khusus Di Kabupaten Kayong Utara
}

\author{
Tasfirani* \\ BAPPEDA Kabupaten Kayong Utara
}

\begin{abstract}
The research aims to find out and identify hidden competence of special region teachers in the District of Kayong Utara, and the influence on their performance. The research was conducted through a survey of 76 special region teachers of 35 schools, involving 42 primary school teachers, 22 junior high school teachers, and 12 high school teachers. The research result shows that in general the tendency of special region teachers were still have low self-concept, personality, and motivation, which each of them is in the range of 2-3. Specifically, the hidden competence tendency of 42 special region teachers of primary school were still low (in the range of 2-3). The hidden competence tendency of 22 junior high school teachers were still low although they are higher than the hidden competence of primary school teachers (in the range of 2-3 on a scale of 5). The performance of special region teachers of primary school, junior high school, and high school also tend to be low for primary teachers (2.98), and high for junior high school teachers (3.39), and senior high school (3.62). The regression results show that there were significant hidden competence on teacher performance with a contribution of $32.5 \%$.
\end{abstract}

Keywords : Hidden Competence, Kinerja, Guru, Daerah Khusus.

\section{PENDAHULUAN}

Kompetensi didefinisikan sebagai karakteristik yang mendasari seseorang (pegawai) dan berkaitan dengan efektivitas kinerja individu(Mitrani et al.,1992 dan Spencer \& Spencer, 1993). Pengertian kompetensi ini diperjelas Ganggani et al. (2006) yang menyatakan bahwa kompetensi sebagai karakteristik yang mendasari seseorang dalam suatu tugas/kerja tertentu, berupa motivasi, bakat, konsep diri, sikap atau nilai, pengetahuan, atau keterampilan kognisi atau perilaku dari seseorang yang dapat diukur secara tetap (reliability) dan dapat ditunjukkan untuk membedakan secara signifikan antara yang ahli dan yang rata-rata atau yang bekerja efektif dan tidak.Karakteristik yang mendasar dari seseorang tersebut adalah pengetahuan, keterampilan, perangai/sifat, konsep diri (Vathanophas dan Thaingam, 2007), dan motive (Spencer \& Spencer, 1993). Karakteristik ini diklasifikasikan menjadi kompetensi yang tampak (visible competence)

*Korespondensi: Tasfirani, BAPPEDA Kabupaten Kayong Utara, Jl. Bhayangkara Sukadana KKU, Kode Pos 78852. Email : tas_fir@yahoo.com 
dan kompetensi yang tersembunyi (hidden competence) (Decker, Stratder, dan Wise, 1997a; Spencer \& Spencer, 1993).

Kompetensi yang tidak tampak (hidden competence) seperti motif, sifat, dan konsep diri merupakan pusat kepribadian dan pengetahuan (Spencer \& Spencer, 1993) dan berkaitan dengan prestasi kerja (Hayes, 1979; Spencer \& Spencer, 1993). Pada tingkat bawah sadar dan sadar, motif dan sifat kepribadian menjadi penyebab munculnya tindakan untuk mencapai suatu hasil serta merupakan inti kepribadian (core personality) seseorang (Spencer \& Spencer, 1993).

Dalam dunia kerja, hidden competence merupakan kompetensi dasar (fundamental competencies), yaitu kompetensi yang harus dimiliki oleh semua orang yang kemudian dapat menjadi penentu kesuksesannya (Gangani, 2006). Motivasi (motive) menjadi pendorong seseorang agar konsisten berpikir dan berkeinginan berbuat sesuatu, dan ia yang mengemudikan, mengarahkan, dan menentukan tingkah laku seseorang ke arah dan atau menjauh dari perbuatan atau tujuan tertentu. Sifat kepribadian (traits) digunakan untuk menggambarkan perilaku (Catell, 1946 dan Eysenck, 1967) dan konsep diri (self concept) agar dapat memberikan kepercayaan, nilai, dan gambaran dirinya kepada orang lain (Spencer \& Spencer, 1993). Kompetensi tersembunyi merupakan fakor yang dominan dalam mempengaruhi kinerja individu.

Kinerja adalah prestasi kerja atau hasil kerja (output) baik kualitas maupun kuantitas yang dicapai SDM pada periode waktu tertentu dalam melaksanakan tugas kerjanya sesuai dengan tanggung jawab yang diberikan kepadanya (Mangkunegara, 2002) dan berdasarkan standar kerja yang telah ditentukan (Istiningsih, 2006). Kinerja dipengaruhi oleh 3 (tiga) faktor yaitu (1) faktor individual yang terdiri dari kemampuan dan keahlian, latar belakang, demografi; (2) faktor psikologis yang terdiri dari persepsi, sikap, kepribadian, pembelajaran, dan motivasi; (3) faktor organisasi yang terdiri dari sumber daya, kepemimpinan, penghargaan, struktur, dan job design (Istiningsih, 2006).

Faktor lainnya yang mempengaruhi kinerja khususnya kinerja guru adalah lingkungan dimana guru tersebut bertugas. Tempat tugas yangberpotensi memunculkan masalah terkait dengan kinerja pegawai adalah tempat tugas di daerah khusus. yaitu daerah yang terisolir (terbatasnya aksessibilitas baik transportasi maupun komunikasi), kultur masyarakat cenderung homogen, dipengaruhi oleh kondisi alam dan fanatisme, kualitas sumber daya manusia relatif rendah, keinginan masyarakat tidak terlalu tinggi (hidup apa adanya), beberapa sumber daya manusia yang berkualitas cenderung terpengaruh dengan kultur budaya setempat sehingga mengalami degradasi.Kondisi demikian secara nyata banyak terjadi pada daerah tertinggal. Di seluruh Indonesia terdapat 183 daerah kabupaten di 27 provinsi yang termasuk daerah tertinggal, salah satunya adalah Provinsi Kalimantan Barat. Provinsi Kalimantan Barat, menurut Bappenas (2004) ; KPDT (2014), memiliki 10 kabupaten yang termasuk daerah tertinggal, yaitu Kabupaten Sambas, Landak, Sanggau, Sekadau, Sintang, Melawi, Putussibau, Ketapang, dan Kayong Utara.Kabupaten Kayong Utara, merupakan daerah tertinggal yang masuk dalam wilayah pesisir dan kepulauan, dengan total pulau 103 
(seratus tiga) pulau, tersebar di 4 (empat) kecamatan, yaitu kecamatan sukadana (9 pulau), kecamatan simpang hilir (2 pulau), kecamatan pulau maya dan kepulauan karimata (92 pulau). Berdasarkan Surat Keputusan Bupati Kayong Utara Nomor 127/Disdik-A/IV/2015, tentang penetapan Sekolah di wilayah khusus Kabupaten Kayong Utara tahun 2015, terdapat 38 (tiga puluh delapan) sekolah (23 SD, 12 SMP, dan 3 SMA) berada di daerah khusus yang menyebar di 4 (empat) kecamatan, yaitu Kecamatan Simpang Hilir (Desa Matan Jaya dan Lubuk Batu), Seponti (Desa Sei Sepeti dan Desa Durian Sebatang), Pulau Maya (Desa Dusun Besar dan Desa Dusun Kecil), dan Kecamatan Kepulauan Karimata (Desa Padang, Desa Betok, dan Desa Pelapis).

Fakta dilapangan, kinerja guru yang berada di daerah khusus belum menunjukkan kinerja yang baik, bahkan mengalami penurunan. Indikator ini ditunjukkan dengan kecenderungan meninggalkan tempat tugas, kecenderungan tidak selalu hadir di kelas, kurang kesungguhan dalam melaksanakan tugas, meninggalkan tempat tugas dalam waktu lama, melaksanakan tugas sering hanya dengan memberikan tugas atau catatan, dan kecenderungan melaksanakan tugas berorientasi pada materi (tuntas secara kuantitas). Dalam waktu tertentu secara periodik meninggalkan tempat tugas dalam waktu yang lama, dan tidak sedikit guru meninggalkan tempat tugas secara bergantian dalam periode waktu tertentu. Padahal sebagian diantara mereka sudah mendapat sertifikasi. Namun sertifikasi yang diperoleh belum berdampak secara signifikan pada peningkatan kinerjanya, hal ini didukung oleh hasil penelitian bahwa kinerja guru yang sudah lolos sertifikasi masih belum memuaskan (Wardana, 2013).

Berdasarkan penjelasan di atas, peneliti ingin melakukan kajian lebih lanjut tentang keterkaitan antara rendahnya kinerja guru di daerah khusus dengan rendahnya kompetensi tersembunyi (hidden competence). Oleh karena itu, penulis ingin mengidentifikasi kompetensi tersembunyi (hidden competence) guru dan bagaimana pengaruhnya terhadap kinerja mereka.

\section{TINJAUAN PUSTAKA}

\subsection{Hidden Competence}

Karakteristik yang berada dalam bagian tersembunyi dari seorang individu diklasifikasikan sebagai kompetensi tersembunyi (hidden competence) (misalnya Mitrani et al.,1992; Spencer and Spencer, 1993; Hamel \& Prahalad,1994; Sanchez, et al., 1996; Teece et al., 1997; Philip J. Decker, 1997a; Winter, 1999; teori Icer Berg). Karakteristik tersembunyi tersebut (hidden competence) berhubungan dengan kepribadian (personality) yang terdiri dari motivasi (motives), sifat (traits), dan konsep diri (self concept) (Sepncer \& Sepncer, 1993; Barllet \& Ghoshal, 1997; Le Deist \& Winterton, 2005; Teece et al.,1992; Philip J. Decker, 1997a) .

Motive atau Motivasi adalah keinginan yang terdapat pada seorang individu yang merangsang untuk melakukan tindakan (Winardi, 2000:312), dorongan yang menyebabkan ia melakukan sesuatu (Wursanto, 1987:132). Motive merupakan driving force yang menggerakkan manusia untuk bertingkah laku (Moch. As'ad, 1995), sehingga 
iamengemudikan, mengarahkan, dan menentukan tingkah laku ke arah dan atau menjauh dari perbuatan atau tujuan tertentu (Spencer \& Spencer, 1993). Ada dua jenis motivasi yang ada dalam individu, yaitu motivasi yang mendorong seseorang untuk berprestasi(Hilgard, Jackson, 1976; David C.McMclelland, 1951) dan motivasi yang mendorong seseorang untuk bekerja (David C.McMclelland, 1951). Motivasi berprestasi merupakan dorongan yang sangat kuat untuk berusaha dan bekerja demi mencapai suatu keberhasilan dan keunggulan (Jackson dalam Hidayat, 2008). Karakteristik orang yang memiliki motivasi berprestasi tinggi adalah memiliki tanggung jawab pribadi yang tinggi, memiliki program kerja berdasarkan rencana dan tujuan yang realistic serta berjuang untuk merealisasikannya, memiliki kemampuan untuk mengambil keputusan dan berani mengambil resiko yang dihadapi, melakukan keinginan menjadi orang terkemuka yang menguasai bidang tertentu (David C. McMclelland dan Edward Muraay). Motivasi bekerja merupakan dorongan yang tumbuh dalam diri seseorang baik yang berasal dari dalam dan luar dirinya untuk melakukan suatu pekerjaan dengan semangat tinggi menggunakan semua kemampuan dan keterampilan yang dimilikinya demi untuk mendapatkan hasil kerja sehingga mencapai kepuasan sesuai dengan keiginannya (As'ad, 1995).

Sifat (traits) terkait dengan karakteristik fisik atau respon yang konsisten terhadap situasi atau informasi (Funder, 2001), dianggap aspek pemikiran yang abadi, perasaan, prilaku yang membedakan orang-orang dari lainya (Catell, 1965; Johson, 1997; McCrae \& Costa, 1997; Cloninger, 2000), menjelaskan perilaku dalam arah yang berbeda (McCrae \& Costa, 1989). Sifat juga di konseptualisasikan sebagai karakteristik individu yang stabil dari waktu ke waktu (Allport \& Odbert, 1936). Allport (1937) menyebutkan 50 makna yang berbeda mengenai sifat kepribadian yang menunjuk pada ilmu agama, philosofi, sosiologi, hukum, dan psikologi. Ada lima dimensi atau factor sifat kepribadian ditinjau dari sudut psikologi (De Raad \& Doddema-Winsemius, 1999; John \& Srivasta, 1999; Wiggins \& Trapnell, 1997; McCrae \& Costa, 1999), yaitu neuroticism, extraversion, openness, agreeableness, dan conscientiousness.

Neuroticism adalah suatu sifat yang mendefinisikan perbedaan individu dalam mengalami pikiran menyenangkan dan ketidakstabilan emosional serta memiliki gangguan pikiran dan tindakan (Clark \& Watson, 1999; McCrae \& Costa, 1992), seperti perasaan sedih, tendensius, depresi, ketidakstabilan emosi, dan bahkan temperamental (Borkenau \& Ostendorf, 1990; Digman, 1990; McCrae, 1991; Montag \& Levine, 1994Clark \& Watson, 1999; Costa McCrae, 1992). Extraversion adalah sifat yang mendefinisikan preferensi individu untuk berprilaku sosial dan aktivitas hidup, dan termasuk karakteristik seperti sosialisasi, suka berteman, demisioner (outgoing), lebih memilih kelompok banyak orang, aktif, menyukai kegembiraan, dan optimis (Clark \&Watson, 1990; McCrae \& Costa, 1992; Daft, 2002). Openness merupakan suatu sifat yang mendefinisikan kecenderungan individu memiliki imajinasi aktif, sensitivitas, estetika, pertimbangan perasaan batin, preferensi untuk berbagi, rasa ingin tahu intelektual, dan kemandirian (Clark \& Watson, 1999; McCrae \& Costa, 1992). 
Agreeableness merupakan sifat yang mencakup keinginan untuk membantu orang lain, altruism, simpati, dan berkeyakinan bahwa orang lain akan membantu kembali (Daft, 2002; John \& Srivastava, 1999; Digman, 1990; Barrick \& Mount, 1993). Conscientiousness adalah sifat yang mendefinisikan kemampuan individu untuk mengontrol impuls, merencanakan dan mengatur proses yang aktif, melaksanakan tugas, dan cenderung pekerja keras dari orang lain. Sifat dan motivasi berupa sifat kehatihatian, mampu beradaptasi (adaptability), dan proaktif (McCrae \& Costa, 1999).

Terakhir, konsep diri berhubungan dengan sikap seseorang, nilai atau image diri (Spencer \& Spencer, 1993). Konsep diri merupakan sekumpulan karakteristik, sifat, perasaan, image, sikap, kemampuan, dan elemen psikologis lainnya yang mengatributi seseorang (Kobal, 2000), yang kemudian menjadi total penilaian seseorang tentang penampilan/latar belakang dan asal usul, kemampuan dan sumber daya, dan sikap dan perasaan, sebagai kekuatan penyutaradaraan perilakunya (Reglin dan Chinsom, 1992).

\subsection{Kinerja Guru}

Kinerja dapat didefinisikan berdasarkan perspektif perilaku, hasil atau prestasi kerja dan kemampuan melakukan sesuatu. Definisi kinerja menurut perspektif prilaku (unjuk kerja) seperti yang dikemukakan Colquitt, Lepine \& Wesson (2009), adalah nilai dari seperangkat perilaku karyawan yang berkontribusi secara positif atau negatif untuk mencapai tujuan organisasi, yang terdiri dari perilaku tugas, perilaku moral, dan perilaku menantang. Murphy dan Cleveland (1995) mendefinisikan kinerja sebagai kualitas perilaku yang berorientasi pada tugas atau pekerjaan.

Perspektif kedua, mendefinisikan kinerja sebagai hasil atau prestasi (Timpe, 1989; Schermerhon, Hunt \& Osborn, 1991; Robbins, 1996), Menurut prespektif ini, kinerja didefinisikan sebagai suatu tampilan keadaan secara utuh, merupakan hasil atau prestasi yang dipengaruhi oleh kegiatan operasional perusahaan dalam memanfaatkan sumber daya yang dimiliki (Helfert dalam Rivai, 2009), yang ditampilkan sesuai dengan perannya dalam organisasi (Hariandja, 2005). Kemudian juga dimaknai sebagai suatu hasil kerja yang dicapai seseorang (pegawai) dalam melaksanakan tugas-tugas yang dibebankan kepadanya didasarkan atas kecakapan, pengalaman, kesungguhan serta waktu (Hasibuan, 2003), sesuai dengan wewenang dan tanggung jawab masing-masing (Rawirosentono, 1990). Mangkunegara (2001:67) mendefinisikan kinerja sebagai hasil kerja secara kuantitas dan kualitas yang dicapai seseorang pegawai dalam melaksanakan tugasnya sesuai tanggung jawab yang diberikan kepadanya.

Perspektif ketiga dari pemaknaan kinerja adalah dipengaruhi oleh tujuan, motivasi, dan kemampuan. Beberapa pendapat dari beberapa hasil penelitian yang menyatakan kinerja merupakan suatu kemampuan individu untuk mencapai sesuatu, seperti yang dikemukakan oleh Casio, 1992 dalam Rivai dan Basri (2005:14), tugas serta kemampuan untuk mencapai tujuan yang telah ditetapkan. Mondy and Premeaux dalam Rivai dan Basri (2005:14), kinerja merupakan suatu fungsi dari motivasi dan kemampuan. Untuk menyelesaikan tugas atau pekerjaan, seseorang harus memiliki 
derajat kesediaan dan tingkat kemampuan tertentu. Kesediaan dan keterampilan seseorang tidaklah cukup efektif untuk mengerjakan sesuatu tanpa pemahaman yang jelas tentang apa yang akan dikerjakan dan bagaimana mengerjakannya. Sinambela, dkk (2007) mendefinisikan kinerja pegawai sebagai kemampuan pegawai dalam melakukan sesuatu dengan keahlian tertentu. Benardin dan Russel (1993) mengatakan bahwa kinerja pegawai tergantung pada kemampuan, usaha dan kesempatan kerja yang dapat dinilai dari output.

Kinerja yang baik harus selalu dilakukan penilaian agar prestasi kerjanya dapat dilihat. Bahkan beberapa definisi kinerja mengandung makna penilaian, seperti yang dikemukakan oleh Ruky (2004) bahwa kinerja ialah suatu penilaian periodik atas nilai seseorang yang berada dalam posisi untuk mengamati atau menilai prestasi kerjanya; Dale S. Beach (dalam Ruky, 2004:12) mengemukakan performance adalah sebuah penilaian sistematis atas individu karyawan mengenai prestasi dalam pekerjaannya dan potensinya untuk pengembangan selanjutnya. Rika Rahmawati dalam penelitiannya menyatakan bahwa prestasi karyawan terkait dengan individu dalam hubungan kerja adalah pemahaman instruksi kerja, penguasaan materi, kualitas kerja, kerjasama dalam pekerjaan, inisiatif dan tanggung jawab kerja, penyesuaian diri terhadap lingkungan kerja, kemauan untuk maju dan berkembang.

Kinerja dinyatakan baik dan sukses jika tujuan yang diinginkan dapat tercapai dengan baik (Donelly, Gibson and Ivancevich, 1994 dalam Rivai dan Basri 2005:14). Pencapaian tujuan yang telah ditetapkan merupakan salah satu tolok ukur kinerja individu. Ada tiga kriteria dalam melakukan penilaian kinerja indivudu, yakni: (a) tugas individu; (b) perilaku individu; dan (c) ciri individu (Robbin, 1996 dalam Rivai dan Basri, 2005:14).

Berdasarkan beberapa definisi di atas, dapat disimpulkan bahwa kinerja atau prestasi adalah catatan tentang hasil-hasil yang diperoleh dari fungsi-fungsi pekerjaan atau kegiatan selama kurun waktu tertentu (Bernardin dan Russel dalam Ruky, 2002); tingkat pencapaian hasil dalam rangka mewujudkan tugas tertentu perusahaan (Payaman Simanjuntan, 2005); prestasi aktual karyawan dibandingkan dengan prestasi yang diharapkan dari karyawan (Dessler, 2009), prestasi yang diharapkan adalah prestasi standar yang disusun sebagai acuan sehngga dapat melihat kinerja karyawan sesuai dengan posisinya dibandingkan dengan standar yang dibuat.

Standar kinerja masing-masing orang mempunyai perbedaan sesuai jenis pekerjaan, organisasi atau profesi. Standar kinerja merujuk pada tujuan organisasi yang dijabarkan kedalam tugas-tugas fungsional. Standar kinerja guru akan berbeda dengan standar pekerjaan industri, karena masing-masing memiliki spesifikasi tugas/pekerjaan yang bebeda. Seorang pendidik dalam mewujudkan kinerjanya harus memiliki kompetensi yang meliputi kompetensi pedagogik, kompetensi kepribadian, kompetensi sosial, dan kompetensi profesional yang diperoleh melalui pendidikan profesi (PP nomor 74 tahun 2008). 
Menurut Sudjana (1997), terkait dengan konteks keguruan ada sepuluh kompetensi guru yang dapat dijadikan parameter untuk melihat kinerja guru yaitu : (a) menguasai bahan, (b) mengelola program belajar mengajar, (c) mengelola kelas, (d) menggunakan media/sumber belajar, (e) menguasai landasan pendidikan, (f) mengelola interaksi belajar-mengajar, (g) menilai prestasi belajar, (h) mengenal fungsi dan layanan bimbingan penyuluhan, (i) mengenal dan menyelenggarakan administrasi sekolah, dan (j) memahami dan menafsirkan hasil penelitian guna keperluan pengajaraan. Secara spesifik prestasi kerja atau kinerja pendidik tertuang dalam peraturan Meneteri Negara Pendayagunaan Aparatur Negara dan Reformasi Birokrasi Nomor 16 Tahun 2009 dan Permendiknas nomor 35 tahun 2010 tentang juknis pelaksanaan jabatan fungsional guru dan angka kreditnya dan menjadi dasar dalam penilaian kinerja guru/pendidik, yaitu penilaian kinerja guru adalah penilaian dari tiap butir kegiatan tugas utama guru dalam rangka pembinaan karir kepangkatan dan jabatannya.

Berdasaran uraian di atas tampak bahwa kinerja guru merupakan hasil kerja baik secara kualitas dan kuantitas yang dicapai oleh guru dalam melaksanakan fungsinya sesuai dengan tanggung jawab yang diberikan, dilihat dari indikator-indikator : menguasai wawasan pendidik tentang kependidikan, kemampuan profesional pendidik dalam merencanakan program pengajaran, keterampilan guru dalam melaksanakan pembelajaran, kemampuan melaksanakan penilaian hasil belajar siswa, kemampuan melakukan hubungan pribadi dalam PBM, sikap dan kepribadian guru dalam melaksanakan PBM. Semua indikator kinerja tersebut dapat dihat dari tingkat keberhasilan ia mendidik sisiwa yang terdeskripsi dari hasil belajar siswa baik kognitif, afektif, dan psikomotor.

\subsection{Daerah Khusus Kabupaten Kayong Utara}

Semula daerah khusus disebut sebagai daerah 3T (tertinggal, terpencil, dan terluar), terminologi yang diberikan oleh Kementerian Pembinaan Daerah Tertinggal, yaitu daerah terpencil, terluar, dan tertinggal (Permendiknas Nomor 35 Tahun 2010). Daerah khusus adalah daerah yang tepencil atau terbelakang, daerah dengan kondisi masyarakat adat yang terpencil, daerah perbatasan dengan Negara lain. Kemudian daerah terpencil atau tertinggal diartikan sebagai daerah kabupaten yang masyarakat serta wilayahnya relatif kurang berkembang dibandingkan daerah lain di Indonesia (Permen PDT No.07/Per/M/M-PDT/III/2007).

Berdasarkan Permen PDT No.07/Per/M/M-PDT/III/2007, terdapat 6 (enam) kriteria dasar daerah tertinggal, yaitu rendahnya tingkat kesejahteraan dan ekonomi masyarakat (perekonomian), keterbatasan sumber daya alam (rendahnya produktivitas lahan), rendahnya aksessibilitas, terbatasnya ketersediaan sarana dan prasarana (infrastruktur), rendahnya kualitas sumber daya manusia, kemampuan keuangan daerah, dan karakteristik daerah.

Menurut Malik (2008), daerah tertinggal adalah kabupaten yang masyarakat dan wilayahnya kurang berkembang, karena alasan: 1) rendahnya potensi dan pengelolaan 
sumber daya alam; 2) terbatasnya akses pertumbuhan; 3) rendahnya sarana dan prasarana social ekonomi; 4) penduduknya terpencar dan terisolir. Dalam Rencana Aksi Nasional (RAN) - Kementerian Negara Pembangunan Daerah Tertinggal (KNPDT), kondisi dan karakteristik daerah tertinggal dikelompokkan menjadi 4 (empat), yaitu wilayah pedalaman, pesisir, kepulauan dan perbatasan.

\subsection{Penelitian Tedahulu}

Sejumlah penelitian mengenai pengaruh kompetensi terhadap kinerja pegawai masih secara umum (misalnya Purwono, dkk. (2010); Syarah (2012); Sriwidodo \& Haryanto, 2010; Setiawati, 2009; Emmyah, 2009; Fitran, 2012; Listio, 2010) belum melihat kompetensi secara spesifik, yaitu kompetensi yang tampak (visible competence) atau kompetensi yang tersembunyi (hidden competence). Hasil penelitian tersebut menunjukkan terdapat hubungan antara kompetensi dengan kinerja, apabila tingkat kompetensi pegawai tinggi atau ditingkatkan maka kinerja pegawai tersebut akan meningkat, dan sebaliknya.

Belum ditemukan penelitian yang spesifik mengkaji dampak hidden competence terhadap kinerja pegawai, kalaupun ada hanya sebatas telaah teori (theoretical review). Beberapa penelitian yang ada melihat komponen kompetensi tersembunyi (hidden competence) secara terpisah. Misalnya penelitian yang dilakukan oleh Carr (2000); dan Barrick \& Mount (1991), mengkaji hubungan antara sifat kepribadian (traits) dan kinerja pegawai yang hasilnya menunjukkan bahwa sifat kepribadian berpengaruh positif terhadap kinerja pegawai. Penelitian yang dilakukan oleh Victors (2001) dan Alexander (1983), mengkaji hubungan konsep diri (self concept) dan kinerja yang hasilnya menunjukkan bahwa terdapat hubungan positif antara konsep diri pegawai dengan kinerja organisasi dan kinerja individu karyawan. Kemudian hasil penelitian yang dilakukan oleh Wardana (2013), Wuyono, dkk (2010) dan Arifin (2014) mengkaji hubungan motivasi (motive) dan kinerja pegawai yang hasilnya menunjukkan bahwa terdapat hubungan yang positif dan signifikan antara motivasi berprestasi dan kinerja pegawai.

\section{METODE PENELITIAN}

\subsection{Populasi Dan Sampel}

Populasi dalam penelitian ini adalah guru daerah khusus yang sudah disertifikasi dan sudah menerima tunjangan daerah khusus yang berada di wilayah Kabupaten Kayong Utara. Sampel ditentukan sebanyak 76 orang guru daerah khusus yang berasal dari 35 sekolah, yang meliputi 42 guru sekolah dasar, 22 guru sekolah menengah pertama dan 12 guru sekolah menengah atas. Teknik penarikan sampel berupa purposive sampling, yaitu dari populasi 270 guru daerah khusus yang berasal dari 38 sekolah, masing-masing sekolah dipilih 2 guru SD dan SMP dan 4 guru SMA yang merupakan 
guru PNS, minimal golongan 3B, dan atau sudah bersertifikasi serta mendapat tunjangan daerah khusus.

\subsection{Variabel Penelitian}

Identifikasi kompetensi tersembunyi 76 guru menggunakan kuesioner yang disusun mengacu pada indikator hidden competence, yaitu konsep diri dengan dimensi sikap, nilai, dan image diri (Spencer \& Spencer, 1993). Sifat kerpribadian dengan dimensi neuroticism, extraversion, openness, agreeableness, dan conscientiousness (McCrae \& Costa, 1999; Mount \& Barrick, 1998; Wiggins \& Trapnell, 1997). Motivasi dengan dimensi motivasi bekerja dan berprestasi (David C. Mc Mcleland dan Edward Muraay). Informasi kinerja guru diperoleh dari hasil penilaian kinerja guru (PKG) yang dilakukan oleh Kepala Sekolah masing-masing satuan pendidikan daerah khusus dan pengawas pembina sekolah daerah khusus.

\subsection{Skala Pengukuran}

Tingkat kecenderungankompetensi tersembunyi yang dimiliki guru-guru daerah khusus diklasifikasikan kedalam kriteria sangat rendah pada rentang 1-2, rendah 2-3, tinggi 3-4, dan sangat tinggi 4-5 (pada skala 1-5). Dan tingkat kecenderungan kinerja yang dimiliki guru-guru daerah khusus mengacu pada kriteria penilaian kinerja guru yang direkomendasikan oleh Kementerian Pendidikan dan Kebudayan, yaitu skala 0 100 dan dikonversi kedalam skala 1-5 dengan kriteria kecenderungan sangat rendah kinerjanya pada rentang 1-2, rendah pada rentang 2-3, tinggi pada rentang 3-4, dan sangat tinggi pada rentang 4-5.

\subsection{Teknik Analisa Data}

Data yang diperoleh baik hasil kuesioner maupun hasil PKG, diolah dengan menggunakan excel dan SPSS untuk mendeskripsikan hasil identifikasi hidden competence dan kinerja guru daerah khusus. Selanjutnya pengolahan data menggunakan analisis regresi untuk mengetahui pengaruh hidden competence terhadap kinerja guru daerah khusus di Kabupaten Kayong Utara.

\section{TEMUAN DAN PEMBAHASAN}

\subsection{Identifikasi Hidden Competence Guru}

Guru yang diindentifikasi hidden competence nya sejumlah 76 orang, 42 orang guru Sekolah Dasar (SD), 22 orang Sekolah Menengah Pertama (SMP), dan 12 orang guru Sekolah Menengah Atas (SMA). Secara umum kecenderungan guru-guru di daerah khusus memiliki konsep diri, sifat kepribadian, dan motivasi masih rendah, yaitu masingmasing berada pada rentang 2-3. Secara spesifik 42 orang guru SD daerah khusus kecenderungan kompetensi tersembunyinya masih rendah (berada pada rentang 2-3).22 orang guru SMP kecenderungan kompetensi tersembunyinya juga masih rendah meskipun sedikit lebih tinggi dari kompetensi tersembunyi guru-guru SD (berada pada 
rentang 2-3 pada skala 5). Kemudian 12 orang guru SMA memiliki kecenderungan kompetensi tersembunyinya diatas guru-guru SD dan SMP (meskipun masih berada pada rentang 2-3 pada skala 5). Deskripsi kecendrungan kompetensi tersembunyi guru-guru SD, SMP, dan SMA daerah khusus seperti pada diagram berikut.

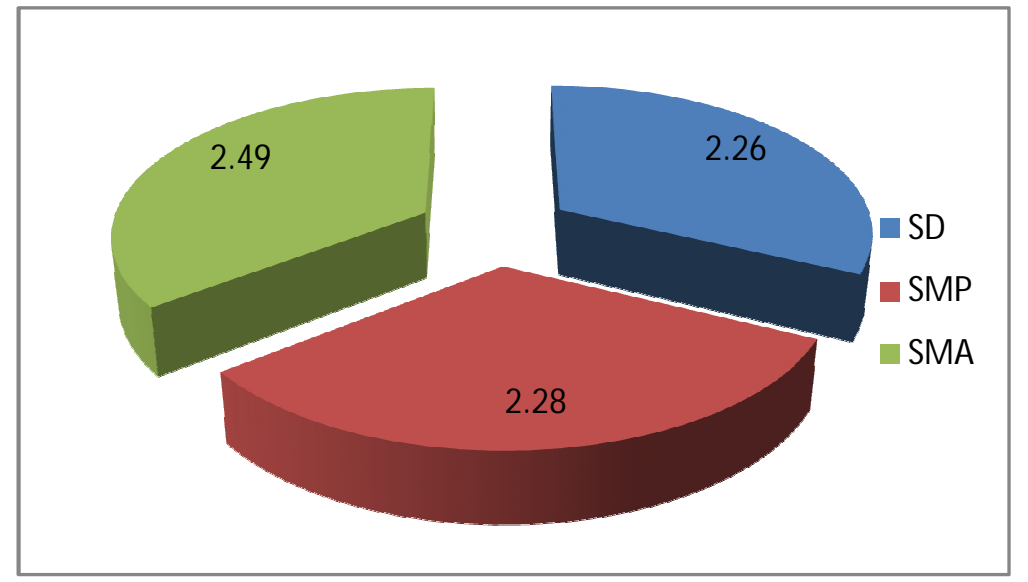

\section{Gambar1. Deskripsi Hidden Competence Guru SD, SMP, dan SMA}

Tingkat kecenderungan kompetensi tersembunyi yang dimiliki oleh guru-guru daerah khusus di Kabupaten Kayong Utara dilihat dari masing-masing komponen, yaitu motive, trait, dan self concept untuk guru SD, SMP, dan SMA dapat dilihat pada diagram di bawah ini.

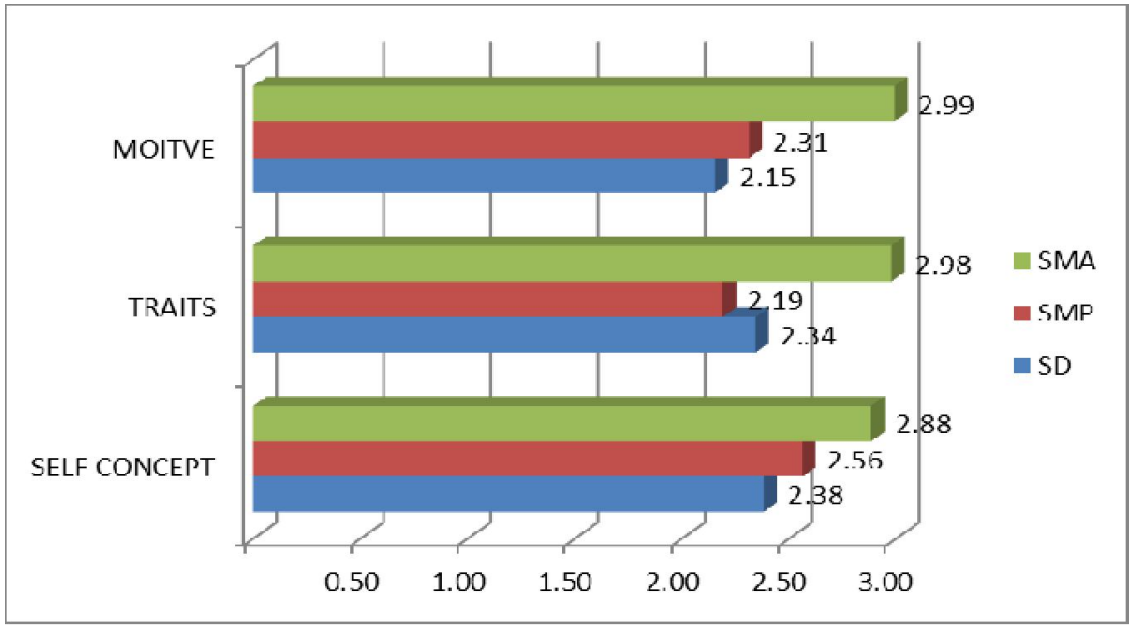

\section{Gambar 2. Deskripsi Komponen Hidden Competence Guru SD, SMP, dan SMA}

Komponen yang masih sangat rendah dibandingkan dari komponen yang lain adalah motive (motivasi) guru-guru, meskipun semua komponen kecenderungannya masih rendah (berada pada rentang 2-3). Motivasi guru-guru SD, SMP, dan SMA daerah khusus kecenderungannya hanya berada pada tingkat rendah dan sangat rendah, masingmasing 2,09 untuk guru SD, 2,14 untuk guru SMP, dan 1,85 untuk guru SMA(pada rentang 1-2 dan 2-3). Kinerja guru-guru SD, SMP, dan SMA daerah khusus 
kencenderungannya masih rendah untuk guru-guru SD $(2,98)$, dan tinggi untuk guruguru SMP $(3,39)$, dan $\operatorname{SMA}(3,62)$.

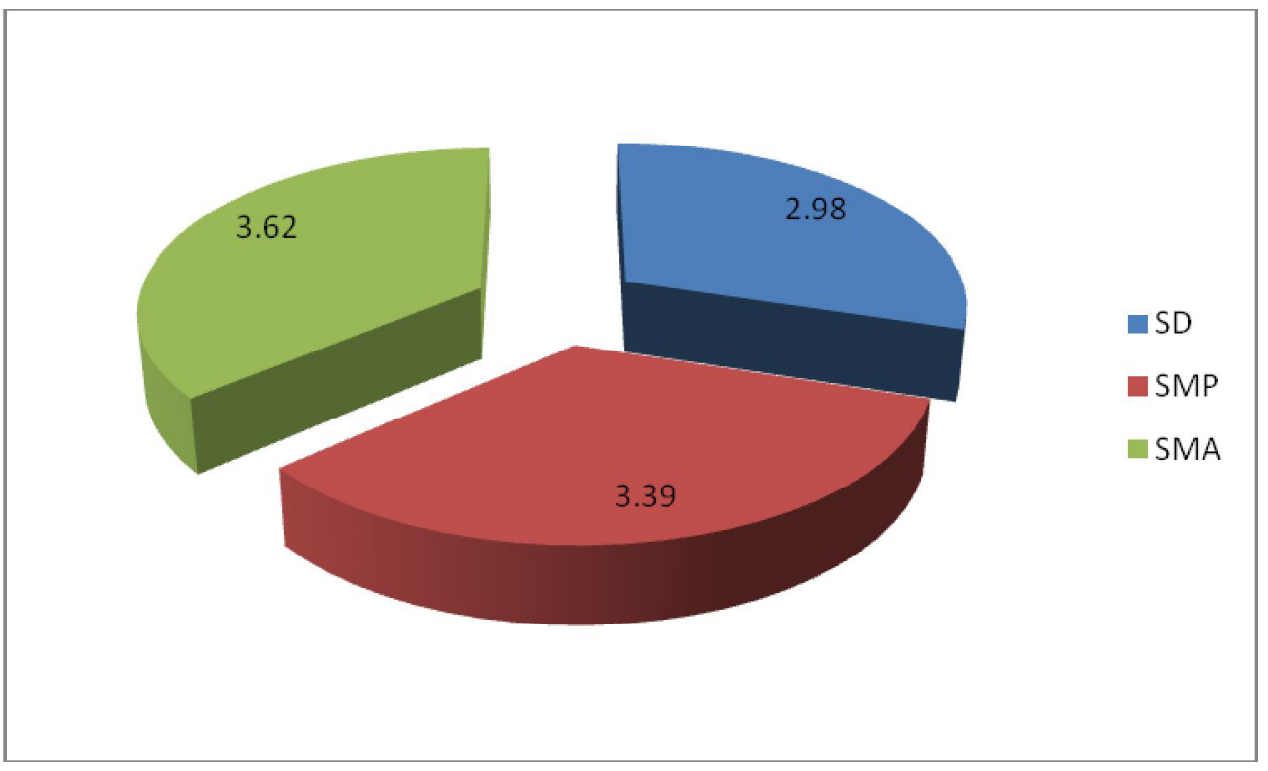

Gambar 3. Deskripsi Penilaian Kinerja (PK) Guru SD, SMP, dan SMA Daerah Khusus

\subsection{Pengaruh Hidden Competence Terhadap Kinerja Guru}

Hasil analisis regresi yang ditunjukkan oleh table coefficient out put regression, diperoleh nilai signifikansi (sig) sebesar 0,000 (kurang dari 0,005/5\%), artinya persamaan regresi linier atau bermakna dengan persamaan regersi $y=a x+b$, dan dapat dipergunakan untuk memprediksi seberapa besar kontribusi hidden competence (variable independen) terhadap kinerja guru (variable dependen).Berdasarkan perolehan nilai $\mathrm{R}$ square pada tabelmodel summary, diperoleh nilai $\mathrm{R}$ square sebesar 0.325 . ini berarti variable independen yaitu hidden competence berimplikasi terhadap peningkatan kinerja guru-guru di daerah khusus dengan kontribusi sebesar 32,5\%, sebesar 67,5\% kinerja guru daerah khusus dipengaruhi oleh faktor lain diluar kajian ini.

\subsection{Pembahasan}

Spencer \& Spencer (1993) berpendapat bahwa kompetensi seseorang diibaratkan seperti gunung es dimana beberapa karakteristik dibawah permukaan air dan beberapa karakteristik di atas. Motivasi dan sifat (berada pada tingkat sadar dan bawah sadar) dan konsep diri (berada pada tingkat cognitive) dikonseptualisasikan sebagai bagian di bawah permukaan air dan tersembunyi (hidden competence), dan merupakan inti kepribadian (core personality). Kompetensi kepribadian inilah (motivasi, sifat, dan konsep diri) merupakan pusat keperibadian dan pengetahuan dan menjadi daya pengungkit (leverage) bagi kompetensi yang tampak (pengetahuan dan keterampilan) (Spencer \& Spencer, 1993) dan berkaitan dengan prestasi kerja yang unggul (Hayes, 1973; Spencer \& Spencer, 1993). Personality ini yang menjadi pendorong seseorang untuk berusaha dan bekerja demi mencapai suatu keberhasilan dan keunggulan (motivasi berprestasi) dan 
menjadi pendorong seseorang untuk melaksanakan pekerjaan secara sungguh-sungguh agar tercapai hasil yang dinginkan (motivasi bekerja).

Bila dilihat hasil regersi di atas, hidden competence memberikan kontribusi sangat besar terhadap kinerja guru daerah khusus yakni sebesar 32,5\%, artinya seeprti yang ditegaskan oleh Spencer \& Spencer (1993), memang konpetensi tersembunyi menjadi pusat kepribadian, menjadi daya pengungkit dan pendorong bagi kompetensi yang visible. Bila kompetensi tersembunyi guru kecenderungan tinggi maka kompetensi visible guru (pengetahuan dan keterampilan) kecencerungannya juga tinggi begitu juga sebaliknya. Rendahnya kompetensi visible guru-guru daerah khusus yang berimplikasi pada rendahnya kinerja mereka disebabkan oleh konsep diri, sifat kepribadian, dan motivasi mereka yang masih rendah. Sehingga memang ada keterkaitan yang logis (logical conection) penyebab kinerja guru daerah khusus rendah karena pengetahuann dan keterampilan mereka rendah, dan penyebabnya adalah konsep diri, sifat kepribadian dan motivasi mereka juga rendah. Bahkan, pada tingkat bawah sadar dan sadar, motivasi dan sifat yang menyebabkan tindakan untuk mencapai suatu hasil (Spencer \& Spencer, 1993) dan menjadi pendorong munculnya nilai, sikap dan konsep diri individu dan menjadi daya pengungkit (laverage) munculnya pengetahuan dan keterampilan, seperti digambarkan berikut ini.

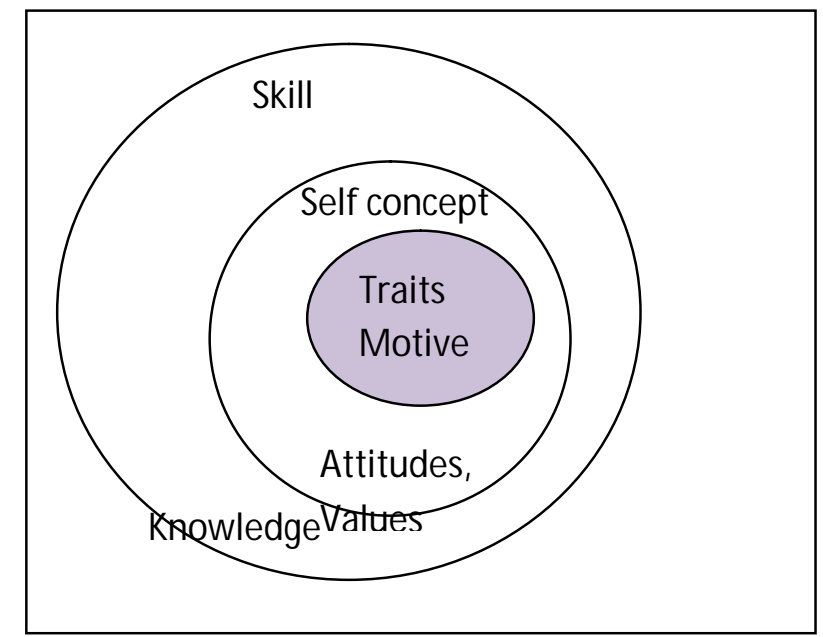

Sumber : Spencer \& Spencer (1993)

\section{Gambar 4. Traits Motive}

Dalam dunia kerja, kompetensi kepribadian merupakan kompetensi dasar (fundamental competence) yang harus dimiliki seseorang dalam bekerja, baru kemudian kompetensi fungsional (functional competence) yang mengantarkan seseorang mampu melaksanakan tugasnya secara efektif (Gangani, 2006).

Seperti dikemukakan pada pendahuluan, bahwa permasalahan yang dialami oleh sumber daya pendidik (guru) di daerah khusus adalah rendahnya tanggung jawab terhadap tugas, rendahnya motivasi bekerja dan berprestasi, kurang kesungguhan dalam melaksanakan tugas, sering meninggalkan kelas, dan melaksanakan tugas sering hanya 
dengan memberikan tugas (catatan), serta kecenderungan melaksanakan tugas berorientasi pada materi (tuntas secara kuantitas). Permasalahan lain yang terjadi sebagai implikasi dari kondisi daerah seperti itu, sebagian besar guru merasa tidak kerasan tinggal dalam waktu yang lama didaerah mereka bertugas, sehingga mereka dalam waktu tertentu secara periodik meninggalkan tempat tugasdan tidak sedikit guru meninggalkan tempat tugas secara bergantian dalam periode waktu tertentu. Permasalahan-permasalahan seperti tersebut menunjukkan rendahnya kinerja mereka yang pada gilirannya akan berimplikasi pada rendahnya kualitas lulusan serta kualitas pendidikan secara umum.

Kompetensi yang dibutuhkan guru dalam kondisi seperti ini adalah kompetensi yang dapat memberikan penguatan mampu beradaptasi dalam kultur budaya setempat, mampu memicu semangat untuk tetap bekerja secara sungguh-sungguh dan tetap berusaha dan bekerja untuk mencapai suatu keberhasilan dan keunggulan, merasa bangga bila peserta didiknya berhasil, serta terdorong untuk meningkatkan pengetahuan dan keterampilan terkait dengan profesinya sebagai seorang pendidik, juga terdorong untuk masuk kerja tepat waktu, jarang beristirahat, dan selalu hadir melaksanakan tugasnya (Wardana, 2013). Kompetensi seperti ini seperti dijelaskan sebelumnya adalah kompetensi yang menjadi daya pengungkit (laverage) bagi berkembangnya pengetahuan dan keterampilan, yaitu kompetensi kepribadian (personality competence). Guru harus memiliki konsep diri, motivasi dan sifat kepribadian yang kuat sehingga lahirlah ketulusan (sincerity) dalam melaksanakan tugas.

Ketulusan yang dimiliki akan menjadi pendorong semangat dan motivasi untuk tetap bekerja secara sungguh-sungguh dan berkeinginan untuk berprestasi. Disamping itu dengan kesadaran yang tinggi muncul rasa tanggung jawab yang tinggi terhadap pekerjaan, karena mereka akan berasumsi bahwa pekerjaan yang diemban merupakan manifestasi dari rasa tanggung jawab vertikal kepada Tuhan Yang Maha Esa dan tanggung horizontal kepada peserta didik dan masyarakat serta manifestasi dari rasa syukur kepada yang Maha Kuasa.Kompetensi tersembunyi (Hidden Competence) yang dimiliki guru-guru daerah khusus dapat memunculkan semangat untuk dapat tetap betah dan kerasan bertugas di daerah khusus, karena seperti teori IceBerg (gunung es) (Spencer \& Spencer, 1993) justru kompetensi tersembunyi inilah (konsep diri, motivasi, dan sifat kepribadian) yang mampu menumbuhkan komitmen dan membangkitkan semangat untuk tetap melaksanakan tugas dimanapun ia berada dan dalam kondisi seperti apapun.

\section{PENUTUP}

\subsection{Kesimpulan}

Berdasarkan hasil identifikasi hidden competence guru-guru SD, SMP, dan SMA daerah khusus di Kabupaten Kayong Utara diperoleh bahwa hidden competence guru SD cenderung rendah berada pada rentang 2-3 (2,26), hidden competence guru-guru SMP cenderung rendah berada pada rentang 2-3 (2,28), dan hidden competence guru-guru SMA juga cenderung rendah masih berada pada rentang 2-3 $(2,49)$, meskipun sedikit 
lebih tinggi dari hidden competence guru SD dan SMP. Dilihat dari masing-masing komponen hidden competence, komponen yang sangat rendah dibandingkan komponen lain adalah komponen motive (motivasi), masing-masing motivasi guru-guru SD masih cenderung masih rendah (2,09), motive guru-guru SMP kecenderungannya juga masihrendah $(2,14)$, dan komponen motive pada guru-guru SMA juga masih sangat rendah (1,85).Hidden competence (berupa konsep diri, sifat kepribadian, dan motivasi) guru-guru daerah khusus memberikan kontribusi sebesar 32,5\% terhadap kinerja guruguru daerah khusus di Kabupaten Kayong Utara.

\subsection{Rekomendasi}

Beberapa rekomendasi dapat penulis berikan berlandaskan pada kesimpulan yang didapat dari hasl analisis dan pembahasan. Pertama, penguatan kompetensi guru hendaknya diawali dengan peningkatan kompetensi tersembunyi guru, sebab dengan meningkatkan kompetensi tersembunyi (hidden competence) mereka, akan mendorong (leverage) berkembangnya kompetensi yang tampak (visible) yang mereka miliki. Kedua, upaya peningkatan kompetensi tersembunyi (hidden competence) guru hendaknya lebih difokuskan pada komponen motive(motivasi) yang dapat dilakukan melalui peningkatkan motivasi mereka dalam melaksanakan tugas. Ketiga, besarnya kontribusi pengaruh kompetensi tersembunyi (hidden competence) terhadap kinerja guru-guru daerah khusus dapat dijadikan bahan pertimbangan untuk melakukan penguatan kompetensi guru-guru daerah khusus agar semakin meningkatkan kinerja para guru di daerah khusus.

\section{DAFTAR PUSTAKA}

Allport,G. W. (1937). Personality- A Psychological Interpretation. New York: Henry Holt and Company.

Allport, G. W. (1937). Concept of Traits and Personality. Psychological Bulletin, 24, 284-293. Retrieved from http://psychclassics.Yorku.ca/Allport/Concepts.htm.

Allport, G. W., \& Odbert, H. S. (1936). Trait Names: A Psycho-Lexical Study Psychological Monogram, 47,211.

Badan Perencanaan Pembangunan Nasional, (2004). Kajian Strategi Pengembangan Kawasan Dalam Rangka mendukung Akselerasi Peningkatan Daya Saing Daerah. Jakarta.

Barrick, M. R., \& Mount, M. K. (1993). Autonomy as a Moderator of The Relationship Between the Big Five Personality Dimension and Job Performance. Journal of Applied Psychology, 78, 111-118. 
Bernadin H. J. \& Rusel. (1996). Human Resource Management. New York: Mc GrawHill, Inc.

Borkenu, P., \& Ostendorf, F. (1990). Comparing Exploratory and Confirmatory Factor Analysis: A Study on The 5- Factor Model of Personality. Personality and Individual Differences, 11, 515-524.

Catell, R. B. (1965). The Scientific Analysis of Personality. Chicago: Aldine Publishing Company.

Clark, L. A., \& Watson, D. (1999). Temperament: A New Paradigm for Trait Psychology. In L.A. Pervin \& O.P. John (Eds.), Handbook of Psychology ( $2^{\text {nd }}$ ed). New York: Guilford Press.

Cloninger, S. C. (2000). Theories ofpersonality: Understanding persons (3rd ed.). Upper Saddle River: Prentice-Hall.

Cloninger, C. R., Prybeck, T. R., Svrakic, D. M., \& Wetzel, R. D. (1994). The Temperament and Character Inventory (TCI): A Guide to Its Development and Use. St. Louis: Center for Psychobiolo.

Colquitt, J., Lepine, J. \& Wesson, M. (2009). Organizational Behavior: Improving Performance and Commitment in The Workplace. New York: McGraw-Hill/Irwin.

Daft, R. L. (2002). The Leadership Experience. Orlando: Harcourt College Publisher.

Dessler, G. (2009). Manajemen SDM buku 1. Jakarta: Indeks

Digman, J. M. (1990). Personality Structure: Emergence of the Five Factor Model. Annual Review of Psychology, 41, 417-40.

Decker, P. J. (1998). The JCAHO has Provided a Tool to Change your Workforce: Are You Paying Attention? Healthcare Supervisor, 16(3): 54-62.

Decker, P. J., M. Strader, and B. Wise. (1997). Beyond JCAHO: Using Competency Models to Improve Healthcare Organizations: Part 1. Hospital Topics, 75(1): 2328.

Wardhana, D. S. (2013). Motivasi Berprestasi dengan Kinerja Guru yang Sudah Disertifikasi. Jurnal Ilmiah Psikologi Terapan, 1(1), 97- 107.

Gangani, N., McLean, G. N., \& Braden, R.A. (2006). A competency-based human resource development strategy. Performance Improvement Quarterly, 19, 1, 12714. Diambil pada 10 Januari 2007, dari http://proquest.umi.com/pqdweb 
Hayes J. (1979). A New Look at Managerial Competence: The AMA Model for Worthy Performance. Management. Review, 59, 2-3.

Funder, D. C. (2001). The Personality Puzle (2 ${ }^{\text {nd }}$ ed.). New York: Norton.

Hamel, G., Prahalad, C. K. (1994). Competing for the Future. Boston: HBS Press.

Hidayat, S. (2008). Hubungan minat terhadap profesi guru dan motivasi berprestasi dengan keterampilan mengajar. Jurnal Pendidikan dan Kebudayaan, 1140.

Johnson, J.A. (1997). Unit of Analysis for The Description and Explanation of Personality. In R. Hogan, J. Johnson \& S. Briggs (Eds.) Handbook of Personality Psychology. San Diego: Academic Press

John, O. P., \& Srivastava, S. (1999). The "Big Five" Trait Taxonomy: History, Measurement, and Theoretical Perspectives. In L. Pervin \& O. P. John (Eds.) Handbook of Personality: Theory and Reseacrh (2 ${ }^{\text {nd }}$ ed.). New York: Guilford Press.

Kementerian Pendidikan dan Kebudayaan. (2012). Pedoman Pelaksanaan Kinerja Guru. Jakarta: Depdikbud.

Mangkunegara, A. P. (2002). Manajemen Sumber Daya Manusia Perusahaan. Bandung: PT Remaja Rosdakarya.

McClelland, D. C. (1951). Personality. New York: William Sloane.

McCrae, R.R. (1991). The Five Factor Model and Its Assesment in Clinical Setting. Journal of Personality Assesment, 57, 399-414.

McCrae, R. R. and Costa, P. T., Jr. (1989). The Structure of Interpersonal Traits: Wiggins's Circumplex and Five Factor Model. Journal of Personality and Social Psychology, 56(4), 586-95.

McCrae, R. \& Costa, P. (1991). The NEO Personality Inventory: Using the Five Factor Model in Counseling. Journal of Counseling \& Development, 69, 367-372.

McCrae, R. \& Costa, P. T., Jr. (1992). The NEO Five Factor Inventory (NEO-FFI). Spanish Translation: Inventory de Personalidad NEO Revisado (NEO PI-R). Inventario NEO reducido de cinco factores (NEO-FFI). Madrid: TEA, 1999). Odessa, FLA: PAR Psychological Assesment Resources.

McCrae, R. R., \& Costa, P. T., Jr. (1997). Personality Traits Structure as a Human Universal. American Psychologist, 52(5), 509-516. 
McCrae, R. R., \& Costa, P. T. ,Jr. (1999).A Five Factor Theory of Personality. In L. A. Pervin \& O. P. John. (Eds). Handbook of Personality: Theory and Research, $2^{\text {nd }} e d$. Guilford, New York, NY.

Mitrani, A., Dalziel, M. \& Fitt, D. (Eds.). (1992). Competency Based Human Resource Management: Value-Driven Strategies For Recruitment, Development And Reward. London: Kogan Page.

Montag, L. \& Levin, J. (1994). The Five Factor Personality Model in Applied Setting European. Journal of Personality, 8, 1-8.

Peraturan Pemerintah Nomor 74 Tahun 2008 tentang Guru.

Peraturan Menteri Negara Pendayagunaan Aparatur Negara dan Birokrasi Nomor 16 Tahun 2009 tentang Petunjuk Teknis Pelaksanaan Jabatan Fungsional Guru dan Angka Kreaditnya.

Peraturan Menterian Pendidikan Nasional Nomor 35 Tahun 2010 tentang Petunjuk Teknis Pelaksanaan Jabatan Fungsional Guru dan Angka Kreditnya.

Peraturan Menteri Daerah Tertinggal No.04/Per/M-PDT/II/2007 tentang Pedoman Umum dan Penetapan Alokasi Dana Stimulan Penyusunan Strategi Daerah Percepatan Pembangunan Daerah Tertinggal dan Penyusunan Rencana Aksi Daerah Percepatan Pembangunan Daerah Tertinggal Provinsi dan Kabupaten Tertinggal.

Peraturan Menteri Daerah Tertinggal No.07/Per/M-PDT/III/2007 tentang Penyesuaian Strategi Nasional Pembangunan Daerah Tertinggal (STRANAS PDT) menjadi Strategi Nasional Percepatan Pembangunan Daerah Tertinggal (STRANAS PPDT).

Peraturan Bupati Kayong Utara Nomor 127/Disdik-A/IV/2015 tentang Penetapan Sekolah di Wilayah Khusus Kabupaten Kayong Utara Tahun 2015.

Rivai, V., \& Basri, A. F. M. (2005). Performance Appraisal. Jakarta: PT. Raja Grafindo Persada.

Rivai, V. (2009). Manajemen Sumber Daya Manusia Untuk Perusahaan. Jakarta : Rajawali Pers.

Robbins, S. P. (1996). Perilaku Organisasi: Konsep, Kontroversi, Aplikasi, Alih bahasa Handayana Pujaatmaka. Jakarta: PT. Prenhallindo.

Ruky, A. S. (2004). Sistem Manajemen Kinerja. Jakarta : PT. Gramedia Pustaka Utama.

Ruky., A. S. (2002). Sistem Manajemen Kinerja. Jakarta : Gramedia Pustaka Utama. 
Sanchez, R, Heene, A. \& Thomas, H. (1996). Towards The Theory and Practice of Competence Based Competiton. In R. Sanchez, A. Heene \& H. Thomas, (Eds): Dynamics of Competence Based Competition. Oxford: Pergamon.

Simanjuntak, P. J. (2005). Manajemen dan Evaluasi Kerja. Jakarta: Lembaga Penerbit FEUI.

Sinambela, L. P. (2007). Reformasi Pelayanan Publik; Teori, Kebijakan dan Implementasi. Jakarta : PT. Bumi Aksara.

Sukandar, (2006). Undang-Undang Republik Indonesia Nomor 14 Tahun 2005 tentang Guru dan Dosen.Jakarta : Pustaka Candra.

Spencer, L. M., and Spencer, S. M.. (1993). Competence at Work. New York: John Wiley and Sons.

Teece, D. J, Pisano, G. \& Shuen, A. (1997). Dynamic Capabilities and Strategic Management. Journal of Economic Behavior and Organization, 23, 1-30.

Timpe, A. D. (1991). Seri Ilmu dan Seni Manajemen Bisnis : Kepemimpinan. Jakarta: Gramedia.

Ujang, R. (2003). Undang-Undang Republik Indonesia Nomor 20 Tahun 2003 tentang Sistem Pendidikan Nasional (Dilengkapi : UUD Negara RI Tahun 1945 dan Perubahannya, serta Kep. Mendiknas tentang Dewan Pendidikan dan Komite Sekolah). Jakarta : Kloang Klende Putra Timur.

Vathanophas, V. dan Thaingam, J. (2007). Competency Requirements for Effective Job Performance in The Thai Public Sector. Journal Contemporary Management Research, 3(1), 45-70.

Rivai, V. (2004). Kepemimpinan dan Perilaku Organisasi, Edisi Kedua. Jakarta : Raja Grafindo Persada.

Wiggins, J. \& Trapnell, P. D. (1997). Personality Structure: The Return of The Big Five. In R. Hogan, J. Johnson, \& S. Briggs (Eds), Handbook of Personality Psychology San Diego: Academic Press.

Winardi. (2004). Motivasi dan Pemotivasian dalam Manajemen. Jakarta: Raja GrafindoPersada. 